\title{
IMPLEMENTASI TUTOR SEBAYA DALAM KETUNTASAN BELAJAR MATERI BERWUDHU KELAS TINGKAT SEKOLAH DASAR
}

\author{
Elia Sari \\ IAIN SALATIGA \\ eliasari123@gmail.com
}

\begin{abstract}
Abstrack:The main purpose of educational progress was mastery learning. Although, sometimes mastery learning could not be reached maximally. It caused by the teacher used less precise method when they teach, student's lack of interest, uninteresting atmosphere, excessive student. However, it could be counter by teaching methods named "peer tutoring" this method placed students to teach other student in educational progress mastery teaching, in this method the teacher utilized the student's potential as a kid and as a fellow student. In several studies, the effectiveness of peer tutoring to be used in learning methods so as improved mastery learning. Peer tutoring method in mastery learning worked as complement and assist, they did not replace the teacher's duties, it made more flexible time for teacher so they could more focus on student's learning needs. The application of peer tutoring in teaching method made learning situation more comfortable, interesting, active, and more prosocial interaction between students. The advantages and disadvantages are always present in every method, although with proper preparation the weakness could be minimized.
\end{abstract}

Keywords : mastery learning, peer tutoring, methods

Abstrak: Tujuan utama proses pembelajaran adalah ketuntasan belajar. namun terkadang ketuntasan belajar tidak tercapai secara maksimal. Hal ini disebabkan kurang tepatnya metode yang digunakan guru dalam proses kegiatan belajar mengajar, kurangnya minat siswa, suasana yang tidak menarik, kelas yang jumlah murid yang terlalu banyak. Akan tetapi hal ini dapat disiasati guru dengan menggunakan metode tutor sebaya dimana guru memanfaatkan potensi sebagian anak untuk membantu teman sebaya dalam proses belajar tuntas. Dalam beberapa penelitian pernah ada, tutor sebaya ini efektif digunakan sebagai salah satu metode untuk meningkatkan ketuntasan belajar. Tutor sebaya dalam belajar tuntas lebih bersifat melengkapi dan membantu bukan menggantikan tugas guru, penggunaan waktu belajar yang lebih fleksibel dan memungkinkan guru untuk lebih fokus pada kebutuhan belajar anak-anak. Penggunaan tutor sebaya dalam proses pembelajaran membuat situasi pembelajaran lebih menarik, aktif dan terjadinya interaksi prososial yang lebih diantara siswa. Kelebihan dan kelemahan tetap ada dalam setiap metode namun dengan persiapan yang matang, kelemahan ini dapat diminimalisir.

Kata kunci : belajar tuntas, tutor sebaya, metode

\section{PENDAHULUAN}

Kurikulum pendidikan Indonesia saat ini adalah Kurikulum 2013 yang menggantikan Kurikulum 2006 yang telah beberapa saat berlaku. Karakterisitik Kurikulum 2013 ini adalah mempersiapkan generasi Indonesia menjadi manusia yang beriman, produktif, kreatif, inovatif, dan 
afektif serta mampu berperan serta dalam kehidupan nyata dalam masyarakat,bangsa dan negara.

Dalam proses pembelajaran dalam Kurikulum 2013 ada 4 kompetensi yang harus dikuasai yaitu kompetensi spiritual, sosial, pengetahuan dan ketrampilan,yang masing-masing dinyatakan dengan $\mathrm{KI}$ 1, 2, 3 dan 4, sehingga diharapkan produk dari kurikulum 2013 menghasilkan insan indonesia yang: produktif, kreatif, inovatif, afektif melalui penguatan sikap, keterampilan, dan kengetahuan yang terintegrasi Dengan melihat hal tersebut maka mau tidak mau seorang guru dituntut untuk menyampaikan bahan ajar secara cerdas dan kreatif agar keempat kompetensi tersebut dalam dicapai oleh siswa dalam proses pembelajarannya.

Dalam proses pembelajaran yang cerdas dan kreatif, tugas seorang guru hanyalah sebagai fasilitator bagi siswa sehingga siswa dapat menggali materi yang sebanyak-banyaknya selama proses pembelajaran berlangsung.

Ketuntasan belajar menjadi tujuan akhir seorang guru dalam proses pembelajaran. Namun kadangkala seorang guru menemukan kesulitan pada saat menerangkan satu materi tertentu kepada siswa yang tertentu pula. Penjelasan dengan berbagai metode sudah dilakukan tetapi ketuntasan belajar belum sesuai dengan yang diharapkan. Hal tersebut dimungkinkan karena siswa kurang dapat memahami penjelasan yang disampaikan oleh guru, baik karena keterbatasan pencapaian daya untuk mengembangkannya atau guru yang bersangkutan belum menemukan metode yang tepat.

Pada kelas gemuk (besar jumlah siswanya), problem-problem semacam ini sering ditemui. Peningkatan jumlah siswa ditambah dengan sumber daya yang berkurang sering menghasilkan ukuran kelas yang lebih besar, sehingga mendorong kembali ke gaya pengajaran tradisional.

Peletakan dasar dari segala kegaiatan ibadah adalah bersuci. Salah satu bagian bersuci adalah wudhu. Wudhu adalah satu syarat ibadah 
wajib yang dilakukan oleh umat Islam. Tanpa wudhu shalat yang dilakukan seseorang tidak akan syah.. wudhu. Wudhu . Pada Kurikulum 2013 materi pendidikan dan praktek berwudhu diletakkan pada kelas 2 semester 1 .

Dari paparan diatas muncul beberapa pertanyaan antara lain ;

1. Bagaimanakah dinamika mastery learning dalam perkembangan pendidikan di Indonesia?

2. Apakah kelebihan dan kekurangan tutor sebaya dalam implementasi pembelajaran?

3. Bagaimanakah implementasi tutor sebaya dalam pencapaian mastery learning pada materi wudhu?

Adapun tujuan penulisan ini adalah untuk membantu memperoleh pemahaman yang lebih baik mengenai dinamika mastery learning dalam perkembangan pendidikan di Indonesia, indikator-indikator tutor sebaya yang mendukung pencapaian mastery learning, kelebihan dan kekurangan tutor sebaya dalam implementasi pembelajaran dan implementasi tutor sebaya dalam pencapaian mastery learning pada materi wudhu.

\section{METODE}

\section{Pendekatan Dan Jenis Penelitian}

Penelitian ini menggunakan pendekatan kualitatif, dengan jenis diskriptif kualitatif dengan melhat fenomena yang terjadi di lapangan tempat penulis berinterkasi sehari-hari dengan menghubungkan antar variabel yang muncul di lapangan serta pengaruh yang didapat.

\section{HASIL PENELITIAN}

Di Indonesia, gagasan mastery learning ini dipopulerkan oleh Badan Penelitian dan Pengembangan Pendidikan dan Kebudayaan yang dikaitkan dengan pembaharuan kurikulum, yaitu kurikulum tahun 1975 dan Proyek Perintis Sekolah Pembangunan (PPSP) di delapan kota yaitu Jakarta, Bandung, Yogyakarta, Semarang, Surabaya, Malang, Ujung Pandang, dan Padang. Percobaan sistem pendidikan yang dilaksanakan pada PPSP tersebut menerapkan kurikulum baru sekolah pembangunan. Semua bidang studi disusun menurut pola baru dan komponen-komponen 
kurikulum dioperasionalisasi ke dalam bentuk-bentuk yang nyata. Tujuan diklasifikasikan menjadi empat tahap, yaitu tujuan pendidikan nasional, tujuan institusional, tujuan kurikuler, dan tujuan instruksional (umum dan khusus). Proses pembelajaran menggunakan sistem modul (modular instruction) yang menerapkan pendekatan mastery learning $(\mathrm{AH}$. Hernawan,2008)

Perkembangan terkini, Kurikulum 2013 meskipun secara eksplisit tidak menyebutkan adanya ketuntasan belajar dalam setiap proses pembelajaran namun kewajiban untuk mencapai empat kompetensi inti yang harus dicapai siswa dengan melalui empat proses dalam setiap proses pembelajarannya telah mengisyarakan keharusan adanya ketuntasan belajar.

Belajar Tuntas atau Mastery Learning adalah proses belajar yang bertujuan agar bahan ajaran dikuasai secara tuntas, artinya cara menguasai materi secara penuh.

Konsep belajar Tuntas merupakan suatu falsafah pembelajaran yang tepat, sehingga semua siswa dapat mempelajari semua bahan yang diberikan dengan hasil yang baik. Sebagian besar siswa dapat menguasai apa yang diajarkan kepadanya, dan tugas pembelajaran adalah mengkondisikan lingkungan belajar yang memungkinkan siswa menguasai bahan pembelajaran yang diberikan.( Suwarno wiji:2006)

Yang menjadi tuntutan dari konsep belajar tuntas adalah penguasaan siswa atas satu konsep pembelajaran, dengan melalui berbagai tahapan evaluasi tanpa ditentukan oleh waktu.

Dalam Aliran Naturalisme yang dipopulerkan oleh J.J Rousseau, tokoh aliran pendidikan dari negara Perancis yang hidup pada tahun 17121778 menyatakan bahwa setiap anak yang lahir di dunia mempunyai pembawaan baik, namun pembawaan tersebut akan menjadi rusak karena pengaruh lingkungan.

"Pembawaan baik" yang kami tangkap disini adalah kemampuan untuk mengerti dan bisa, sehingga asumsi awal yang muncul adalah tak 
ada siswa yang tak memiliki kemampuan berfikir sama sekali. Dan berangkat dari aliran Naturalisme, kita berasumsi bahwa pada dasarnya setiap anak memiliki kemampuan, meskipun dalam tempo yang berbeda.

Perspektif John Carroll mengenai bakat, siswa yang memiliki bakat rendah akan membutuhkan waktu yang lebih lama untuk bisa menguasai materi tertentu dibanding siswa yang memiliki bakat lebih tinggi.(Bruce Joyce, Marsha Weil, Emily Calhoun:2011:409). Sehingga dapat dikatakan semua siswa memiliki kemampuan untuk mempelajari materi secara tuntas selama diberikan waktu yang cukup untuk mempelajarinya.

Bloom mengemukakan bahwa meskipun para siswa sangat bervariasi dalam tingkat dan modalitas belajar mereka, jika guru dapat memberikan waktu yang diperlukan dan kondisi belajar yang sesuai, hampir semua siswa dapat mencapai tingkat prestasi yang tinggi.( Guskey, TR:2010)

Cara penerapan suatu pembelajaran akan berpengaruh besar terhadap kemampuan siswa dalam mendidik diri mereka sendiri. Guru yang sukses buka sekedar penyaji yang kharismatik dan persuasif. Lebih jauh, guru yang sukses adalah mereka yang melibatkan para siswa dalam tugas-tugas yang sarat muatan kognitif dan sosial, dan mengajari mereka bagaimana mengerjakan tugas-tugas tersebut secara produktif (Hill, F. Winfred,2010:7)

Untuk mempermudah proses pencapaian ketuntasan belajar satu hal yang harus dibangkitkan pada diri siswa adalah minat terhadap materi yang akan diajarkan. Minat dapat terwujud dengan adanya keinginan untuk memahami. Menurut Jackling hal tersebut dikenal dengan pendekatan mendalam. Deep Approaches to learning is characterized by a desire to understand underlying principles (Pendekatan mendalam untuk belajar ditandai dengan keinginan untuk memahami prinsip-prinsip yang mendasarinya). (Jackling B,2012). Pendekatan yang mendalam atau deep approaches adalah munculnya rasa ketertarikan siswa pada hal-hal yang berkenaan dengan materi yang akan disampaikan. 
Dan bila siswa sudah memiliki kertarikan yang mendalam terhadap materi yang akan disampaikan (Jackling B,2012) maka proses pembelajaran akan relatif lebih mudah untuk berlangsung dengan lebih menyenangkan.

Pengajaran yang baik adalah pengajaran yang dapat merangkul semua pengalaman belajar anak didik tanpa batas, dapat membawa semua pengalaman belajar itu untuk proses pembelajaran yang ada.

Situasi siswa yang dinamis membutuhkan sosok guru cerdas dan kreatif yang dapat membantu siswa untuk mencapai belajar tuntas. Seorang guru dituntut agar dapat membangkitkan kreatifitas dan keaktifan belajar siswa, sehingga apa yang menjadi pokok materi saat itu secara totalitas dikuasai anak.

Mastery learning is an instructional approach in which educational progress is based on demonstrated performance, not curricular time. Learners practice and retest repeatedly until they reach a designated mastery level; the final level of achievement is the same for all, although time to mastery may vary. (Belajar tuntas adalah pendekatan instruksional di mana kemajuan pendidikan didasarkan pada kinerja yang ditunjukkan, bukan waktu kurikuler. Siswa berlatih dan menguji ulang berulang kali hingga mencapai tingkat penguasaan yang ditentukan; tingkat pencapaian akhir adalah sama untuk semua orang, meskipun waktu untuk penguasaan dapat bervariasi). (Yudkowsky, R., Park, Y. S., Lineberry, M., Knox, A., \& Ritter, E. M,2015).

Psikolog Amerika John B. Carroll menerima penghargaan karena memengaruhi konsep penguasaan pembelajaran. Carroll percaya bahwa semua siswa memiliki bakat untuk belajar tetapi beberapa dari mereka membutuhkan lebih banyak waktu untuk mencapai penguasaan. Persepsi penguasaan siswa adalah bahwa jika siswa tidak belajar, guru perlu mengubah pendekatan dan menyajikan materi dengan cara yang berbeda yang membuatnya lebih mudah diakses oleh siswa, 
Belajar tuntas (Mastery Learning) menuntut siswa menguasai secara tuntas seluruh standar kompetensi maupun kompetensi dasar mata pelajaran. Ketuntasan belajar siswa diukur dengan adanya program perbaikan/program remedial, yakni jika siswa tidak diperkenankan untuk untuk ke materi berikutnya bila belum mencapai standar ketuntasan yang ditentukan, dan bila belum mencapai ketuntasan yang ditetapkan, maka siswa diberi program perbaikan sampai mencapai ketuntasan.

Untuk mengetahui ketentuan didalam mereka mempelajari suatu pengetahuan dengan mengadakan penilaian, yang mana nilai ketuntasan standar kompetensi ideal $=100$. Guru dan sekolah menentukan nilai ketuntasan minimum secara bertahap dan terencana agar memperoleh nilai ideal. Adapun nilai ketuntasan minimum per mata pelajaran ditetapkan berdasarkan tingkat kesulitan dan kedalaman kompetensi dasar yang harus dicapai siswa (dan setiap mata pelajaran nilai ketuntasannya dapat berbeda), namun idealnya penentuan ketuntasan diberikan pada setiap indikator.

Salah satu ciri belajar tuntas adalah pra-penilaian (pre-test) yang dilakukan sebelum topik diajarkan. Pre-test membantu guru mengidentifikasi masing-masing siswa pada awal pembelajaran sehingga materi dan metode pengajaran dapat disesuaikan untuk setiap siswa.

Dalam proses pembelajaran, seorang guru akan memberi umpan balik, dimana dengan umpan balik tersebut seorang guru akan dapat membantu siswa yang pada tahapan pre-test masih menemui kendala untuk mencapai kemajuan hingga mencapai tahap tuntas.

Dan bila dalam pre-test terdapat siswa yang telah menguasai materi dengan pengalaman belajar yang telah didapatkan sebelumnya, maka seorang guru dapat memberikan pengayaan atau materi yang terkait yang lebih dalam kepada siswa yang bersangkutan.

Pendekatan pembelajaran penguasaan mencegah situasi di mana guru mengajar kepada siswa tercepat sambil meninggalkan mereka yang memiliki bakat yang sama tetapi membutuhkan lebih banyak waktu. Penelitian berulang menunjukkan bahwa penguasaan pembelajaran memiliki 
efek positif pada hasil belajar karena siswa tidak boleh menyerah pada pembelajaran materi di kelas. Ini meningkatkan motivasi siswa karena siswa melihat kesuksesan yang lebih besar dan tidak dibuat merasa buruk karena mereka memiliki gaya belajar yang berbeda. Penguasaan pembelajaran memudahkan siswa untuk mencapai karena mereka maju melalui nilai-nilai karena pembelajaran bersifat kumulatif dan penguasaan pembelajaran memastikan bahwa setiap siswa memiliki pemahaman yang memadai tentang suatu topik sebelum bergerak maju. (Ungvarsky, Janine,2017)

Sehingga tahapan-tahapan yang harus ada dalam proses belajar tuntas adalah pertama, menilai semua kompetensi dasar yang pelaksanaan testnya dilakukan pada satu atau lebih kompetensi dasar. Kemudian hasil test dianalisa dan ditindak lanjuti melalui program remedial, bagi yang nilainya belum mencapai Nilai Ketuntasan Minimal (KKM) atau pengayaan, bagi siswa yang nilainya telah mencapai KKM. Kedua, ujian mencakup aspek kognitif, psikomotor, dan efektif. Ketiga nilai akhir semester merupakan nilai kumulatif dari keseluruhan nilai perolehan selama satu semester yang terkait.

Konsep belajar tuntas ini memunculkan tambahan pekerjaan bagi seorang guru, selain membutuhkan banyak waktu untuk melayani siswa yang memiliki kecepatan kurang, juga membutuhkan banyak kreatifitas yang lebih agar siswa memperoleh hasil yang maksimal dalam materi terkait, dimana semua siswa merasa terlayani.

Kesulitan dari metode ini adalah pada sekolah-sekolah negeri, dimana tak jarang terdapat siswa yang berkebutuhan khusus dan siswa yang membutuhkan perlakuan khusus, serta penyampaian materi dibatasi dengan jam tatap muka maka ketuntasan belajar seringkali tidak tercapai secara maksimal. Sebab pada pertemuan berikutnya, guru dituntut untuk menyampaikan materi yang lain untuk memenuhi target materi dalam semester itu.

Solusi yang diambil dalam mengatasi masalah tersebut adalah tetap memberikan remedial terhadap peserta yang berkebutuhan khusus dengan 
KKM yang sama akan tetapi grade atau tingkat kesulitan soal diturunkan sesuai dengan kemampuan siswa tersebut.

Sehinggga pada materi tersebut siswa yang berkebutuhan khusus dan siswa yang berada dalam taraf rata-rata ataupun diatas rata-rata tetap menguasai materi yang diberikan namun dalam tingkatan yang berbeda.

Tingkat penguasaan yang berbeda-beda tersebut memungkinkan munculnya apa yang disebut tutor sebaya atau peer teaching, dimana siswa yang memiliki kemampuan lebih dapat membantu siswa lain yang belum memahami materi dengan bahasa sebaya dengan tetap berada dalam pengawasan guru.

Model pembelajaran Peer Teaching atau tutoring adalah salah satu model yang dikembangkan untuk meningkatkan penguasaan isi akademis siswa terhadap materi yang diajarkan melalui dua tahap, yaitu Peer (Sebaya), dan Teaching (Tutor).

Pembelajaran tuntas sekaligus bermakna sangat mungkin untuk dicapai dengan metode peer tutoring. Pembelajaran yang bermakna (meaningful learning) adalah pembelajaran yang benar-benar memberikan makna kepada siswa.(Subhan, Edy,2016:168). Dimana ilmu yang didapat tidak hanya bersifat teoritis saja, akan tetapi hasil belajar yang dicapai dapat bermanfaat bagi siswa yang masih dalam masa perkembangan dan dapat diaplikasikan dalam kehidupan sehari-hari serta dapat membangun kerangka berfikir yang lebih luas serta memancing keingintahuan siswa lebih lanjut.

Peer tutoring adalah strategi pengajaran yang melibatkan siswa saling membantu belajar konten melalui pengulangan konsep-konsep kunci. (Bowman-Perrott, L., Davis, H., Vannest, K. J., Williams, L., Greenwood, C., \& Parker, R,2013).

Tutor sebaya adalah seorang murid membantu belajar murid lainnya dengan tingkat kelas yang sama. (Susilowati,2009:3-28), sistem pengajaran di mana siswa saling membantu dan belajar dengan mengajar dengan skema bimbingan belajar siswa mengajar siswa, siswa mengajar 
siswa sekolah, orang dewasa non-profesional mengajar orang dewasa dan anak-anak.

Bimbingan teman sebaya berkaitan dengan strategi pengajaran di mana siswa diajarkan oleh rekan-rekan mereka, yang telah dilatih dan diawasi oleh guru kelas. Ini melibatkan meminta siswa bekerja berpasangan dengan siswa lain seusia atau kelasnya. Ini dapat digunakan untuk membantu instruksi beberapa siswa tertentu atau di seluruh kelas dasar.

Tutor sebaya atau peer tutoring adalah seorang siswa yang telah dipilih oleh guru untuk mendampingi temannya dalam proses pembelajaran. Tutor sebaya ini dianggap sebagai metodologi praktik yang sangat sukses dan efektif untuk membantu siswa meningkatkan keterampilan akademik dan sosial mereka .(O'Shea, LJ, \& O'Shea, DJ,2010).

Rasa sungkan dan takut yang mungkin dirasakan siswa saat proses pembelajaran yang dilaksanakan dengan gurunya akan hilang dalam situasi peer tutoring ini. Karena interaksi yang terjadi adalah interaksi kooperatif, akrab dan santai. Dan bila tingkat pemahaman atau keberhasilan belum sesuai dengan yang diharapkan, dapat berpindah ke tutor lain yang dirasa lebih cocok bagi siswa tersebut.

Hal lain yang muncul pada pelaksanaan tutor sebaya, antara lain, interaksi antara guru dan siswa, menumbuhkan minat dan motivasi siswa, suasana yang lebih akrab antara siswa dan guru dalam kegiatan belajar, pembelajaran leih aktif dan mernarik. Tutor sebaya diindikasikan sangat kuat sebagai cara selain untuk meningkatkan akademik, juga memiliki fungsi pencegahan perilaku anti-sosial

Dalam pelaksanaan tutor sebaya diperlukan adanya kerjasama yang tinggi, serta sikap kooperatif. Sebab tanpa kerja sama dan sikap kooperatif dari masing-masing pihak yang terkait dalam pembelaran tutor sebaya ini maka kemungkinan hasil yang dicapai kurang maksimal.

Tutor sebaya dalam belajar tuntas lebih bersifat melengkapi dan membantu, bukan menggantikan tugas guru, penggunaan waktu belajar 
yang lebih fleksibel dan memungkinkan guru untuk lebih fokus pada kebutuhan belajar anak-anak.

Banyak manfaat yang muncul dalam peer tutoring ini. Bagi siswa yang menjadi tutor, akan lebih meningkatkan kepercayaan dirinya, lebih menguatkan apa yang dia pahami menjadi semakin kuat, menumbuhkan sikap simpati dan saling menolong, menghargai orang lain, dan berlatih mengeluarkan pendapat dalam bentuk lesan.

Sedangkan bagi siswa yang diajari, dia akan belajar dalam situasi yang sesuai dengan keinginan dia, belajar menerima dan menghargai kekurangan dan kelebihan yang dimiliki orang lain, lebih mudah memahami apa yang semula tidak dia pahami dari penjelasan guru karena biasanya proses pembelajarannya akan lebih bersifat kooperatif.

Adapun indikator seorang siswa yang dijadikan sebagai tutor sebaya adalah; siswa tersebut memiliki kompetensi yang lebih diantara temanteman sekelasnya dalam materi yang dibahas, memiliki ketrampilan verbal artinya mampu menerangkan pokok-pokok materi,

Banyak penelitian mengenai tingkat efektivitas tutor sebaya dalam ketuntasan belajar, yang kesemuanya memberikan hasil positif diantaranya

Dalam jurnal artikel tulisan Leung. K (2015) yang berjudul "Preliminary empirical model of crucial determinants of best practice for peer tutoring on academic achievement", menyebutkan bahwa penelitian ini menunjukkan bahwa tutor sebaya memiliki dampak positif pada prestasi akademik.

Damon, W. (1984) dalam tulisannya yang berjudul Peer education: The untapped potential. Journal of Applied Developmental Psychology menuliskan Penelitian telah menunjukkan bahwa pembelajaran sebaya dapat meningkatkan harga diri anak-anak, membangkitkan minat mereka dalam tugas-tugas yang menantang, meningkatkan prestasi ilmiah, dan menumbuhkan perilaku prososial. 
Tsuei, M. (2012) dalam Using synchronous peer tutoring system to promote elementary students' learning in mathematics. Computers and Education menyatakan dalam penelitian yang bertujuan untuk mengeksplorasi efek dari sistem tutor sebaya sinkron pada pembelajaran matematika anak-anak mendapatkan kesimpulan bahwa siswa menunjukkan keterampilan penalaran matematika yang berbeda ketika mereka dipasangkan dengan teman sebaya di berbagai tingkat kemampuan. Temuan ini menunjukkan bahwa sistem tutor teman sebaya yang sinkron adalah alat yang efektif untuk meningkatkan pembelajaran siswa SD dalam matematika, serta mempromosikan konsep diri yang positif.

Leung, K. C. (2015), dalam papernya yang berjudul Preliminary empirical model of crucial determinants of best practice for peer tutoring on academic achievement menyimpulkan bahwa tutor sebaya memiliki dampak positif pada prestasi akademik. Moderator dan penentu penting dari efektivitas tutor sebaya diidentifikasi dan dibandingkan. Selain itu, parameter program berdasarkan konsep teori peran dan kontinjensi kelompok saling tergantung dievaluasi. Akhirnya, model empiris awal dari penentu penting dari praktik terbaik untuk tutor sebaya pada prestasi akademik diusulkan. dan melibatkan berbagai peserta dan berbagai mata pelajaran.

Dufrene, B. A., Reisener, C. D., Olmi, D. J., Zoder-Martell, K., McNutt, M. R., \& Horn, D. R. (2010) dalam Peer Tutoring for Reading Fluency as a Feasible and Effective Alternative in Response to Intervention Systems, mengevaluasi kelayakan dan dampak paket bimbingan belajar sebaya untuk membaca kelancaran dengan 4 siswa sekolah menengah yang menerima bantuan perbaikan Tingkat II. Penelitian ini menggunakan desain dasar berganda di antara peserta untuk mengevaluasi dampak dari prosedur tutor sebaya pada tingkat membaca lisan siswa pada bagian pengajaran. Hasil menunjukkan bahwa tingkat membaca lisan siswa pada probe pembelajaran meningkat setelah penerapan prosedur tutor sebaya. 
Selain itu, tutor sebaya menerapkan sebagian besar langkah prosedur dengan tingkat integritas yang tinggi.

Namun penggunaan metode tutor sebaya ini bukannya tanpa hambatan. Beberapa hal yang bisa menjadi penyebab tutor sebaya ini kurang maksimal adalah karena kurangnya persiapan yang dilakukan oleh tutor, sarana dan prasarana yang kurang memadai, tingkat kecakapan tutor dalam menyampaikan materi kepada teman sebaya.

Juga mindset dari sebagian guru bahwa prinsip pembelajaran adalah guru didepan kelas memberikan materi perlu dirubah. Menciptakan suasana belajar yang aktif dengan guru menjadi fasilitator lebih bisa diterapkan.

Agar tutor sebaya menjadi efektif diperlukan kerjasama yang tinggi antara guru, tutor dan tutee. Pembelajaran kooperatif adalah penggunaan instruksional kelompok kecil sehingga siswa bekerja bersama untuk memaksimalkan pembelajaran mereka sendiri dan masing-masing. Pada pelaksanaannya kelas dibagi menjadi beberapa kelompok kecil yang maksimal terdiri dari 5 orang anggota.. Mereka kemudian mengerjakan penugasan sampai semua anggota kelompok memilikinya berhasil memahami dan menyelesaikannya.

Dengan sistem ini akan menumbuhkan semangat juang pada masing-masing anggota kelompok untuk saling kerja sama agar masingmasing kelompok memiliki nasib yang sama dalam keberhasilan memahami dan menyelesaikan tugas yang diberikan oleh tutor.

Adanya saling ketergantungan positif dalam kelompok akan berimplikasi positif pada ketuntasan belajar. sebab mereka akan merasa bahwa bahwa kesuksesan kelompok tergantung pada kesuksesan masingmasing anggota kelompok tersebut.

Pelaksanaan peer tutoring ini dapat dilaksanakan pada saat proses KBM berlangsung dan dapat dilanjutkan di luar KBM apabila waktu tidak memenuhi. 


\section{PEMBAHASAN}

Subjek dari penelitian tindakan kelas ini adalah 24 siswa SD di kelas 2 pada mata pelajaran PAl yang terdiri dari 17 siswa laki dan 8 perempuan. Kelas ini juga memenuhi kriteria heterogen berdasarkan jenis kelamin, kemampuan akademis, dan latar belakang rentang usia antara 8 - 9 tahun.

Dari hasil evaluasi pertama yang diadakan di kelas untuk pelaksanaan praktek wudhu didapatkan 8 anak mengalami kesulitan belajar ditandai dengan banyaknya kesalahan yang dilakukan dalam praktek berwudhu, sehingga ketuntasan belajar belum dapat dicapai.

Dari wawancara yang dilakukan serta pengamatan yang ada diperoleh kesimpulan awal bahwa hambatan itu terletak pada sulitnya menghafal urutan gerakan wudhu yang benar.

Dari kesimpulan awal tersebut, peneliti mencoba untuk menggunakan model tutor sebaya dalam memahamkan dan menuntaskan mereka dalam materi berwudhu.

Adapun teknis pelaksanaan peer tutoring ini ;

1. Guru menyiapkan materi akan disampaikan kepada tutor, yaitu tata cara wudhu. Guru menentukan 5 siswa yang akan ditunjuk menjadi tutor berdasarkan kemampuan tutor.yang diamati pada saat evaluasi yeng pertama.

2. Membagi kelas menjadi 5 kelompok kecil, dengan masing-masing kelompok terdiri 4 orang siswa dan satu kelompok 3 peserta.

3. Guru menjelaskan pada kelas tentang metode tutor sebaya

4. Guru menetapkan aturan yang jelas dan harapan sebelum bimbingan teman sebaya.

5. Tutor diberikan lembar penilaian sederhana dengan penilaian yang menyatakan urut dan tidaknya dalam pelaksanaan wudhu.

6. Tutor memberikan contoh cara berwudhu yang benar, tutee menirukan

7. Tutee mempraktekkan tata cara wudhu yang benar dalam masingmasing kelompok dengan bimbingan dari tutor 
8. Selama pelaksanaan peer tutoring, guru tetap mengawasi dan memberikan arahan bila diperlukan.

Setelah proses tutoring selesai, guru mencoba untuk mengkonfirmasi hasil pembelajaran dengan tutor serta guru kembali mengadakan tinjauan ulang untuk mengetahui sejauhmana ketuntasan yang telah dicapai. Hasil Idari 8 orang yang semula belum tuntas kini menjadi 7 orang tuntas, 1 orang belum tuntas karena termasuk siswa dengan perlakuan khusus.

\section{KESIMPULAN}

Mastery learning yang dikembangkan di Indonesia mengalami perkembangan dengan terus diberlakukannya dalam sistem kurikulum di Indonesia hingga saat ini walaupun secara eksplisit tidak disebutkan dalam Kurikulum 2013 yang berlaku saat ini namun pencapaian empat kompetensi yang menjadi tujuan Kurikulum 2013 juga merupakan ketuntasan belajar.

Kelebihan tutor sebaya adalah meningkatkan prestasi akademik, meningkatkan perilaku pro sosial, memberi kesempatan bagi peserta didik untuk berinteraksi secara verbal dan non-verbal satu sama lain, terjadinya interaksi yang kooperatif, akrab dan santai, pembelajaran sebaya dapat meningkatkan harga diri anak-anak, membangkitkan minat mereka dalam tugas-tugas yang menantang (Damon, W.1984), memberi kesempatan bagi siswa untuk memanfaatkan pengetahuan dan pengalaman mereka dengan cara yang bermakna, menumbuhkan rasa percaya diri dan bagi guru lebih punya waktu untuk mengorganisasi kelas, menumbuhkan kepercayaan diri, tanggung jawab, pertumbuhan keterampilan organisasi, pengambilan keputusan, bereksperimen, mengeksplorasi, mengungkapkan perasaan, empati, dan motivasi

Adapun kelemahan tutor sebaya adalah mindset melanggar cara pengajaran tradisional dan mengubah pola pikir tentang mengajar mungkin sulit bagi beberapa guru, guru mungkin kekurangan keterampilan untuk melatih siswa mereka dengan benar untuk menjadi tutor, munculnya masalah yang mungkin menimbulkan gangguan jika tidak dimonitor dengan 
baik, tutor yang tidak terlatih dimungkinkan menggunakan kekerasan baik fisik atau verbal saat mendapatkan kesulitan, tutor mungkin tidak sepenuhnya memahami materi yang akan diajarkan, tutor sebaya lebih sering bersifat mentransfer pengetahuan daripada mengembangkan

Implementasi tutor sebaya dapat diterapkan dalam mendukung ketuntasan belajar mata pelajaran Pendidikan Agama Islam materi Wudhu dengan hasil yang positif.

\section{Daftar Pustaka}

[1] AH. Hernawan (2008). Makna Ketuntasan Belajar. Majalah IImiah Pembelajaran. Jurnal. uny.ac.id

[2] Tsuei, M. (2012). Using synchronous peer tutoring system to promote elementary students' learning in mathematics. Computers and Education, 58(4), 1171-1182. https://doi.org/10.1016/j.compedu.2011.11.025

[3] Dufrene, B. A., Reisener, C. D., Olmi, D. J., Zoder-Martell, K., McNutt, M. R., \& Horn, D. R. (2010). Peer Tutoring for Reading Fluency as a Feasible and Effective Alternative in Response to Intervention Systems. Journal of Behavioral Education, 19(3), 239-256. https://doi.org/10.1007/s10864-010-9111-8

[4] Leung, K. C. (2015). Preliminary empirical model of crucial determinants of best practice for peer tutoring on academic achievement. Journal of Educational Psychology, 107(2), 558

[5] Berghmans, I., Neckebroeck, F., Dochy, F., \& Struyven, K. (2013). A typology of approaches to peer tutoring. Unraveling peer tutors' behavioural strategies. European Journal of Psychology of Education, 28(3), 703-723. https://doi.org/10.1007/s10212-012-0136- 
[6] Damon, W. (1984). Peer education: The untapped potential. Journal of Applied Developmental Psychology, 5(4), 331-343. https://doi.org/10.1016/0193-3973(84)90006-6

[7] Bowman-Perrott, L., Davis, H., Vannest, K. J., Williams, L., Greenwood, C., \& Parker, R. (2013). Academic benefits of peer tutoring: A metaanalytic review of single-case research. School Psychology Review, 42(1), 39-55. https://doi.org/10.1016/j.jcomdis.2015.06.009

[8] Lutvaidah, U. (2016). Keefektifan Strategi Pembelajaran Antara Metode Tutor Sebaya Dengan Metode Tanya Jawab Dalam. Formatif: Jurnal IImiah Pendidikan MIPA, 6(3), 266-275.

[9] O'Shea, LJ, \& O'Shea, DJ (2010). Peer-Tutoring. Dalam International Encyclopedia of Education (hal. 802-807). Elsevier Ltd. https://doi.org/10.1016/B978-0-08-044894-7.01139-8

[10] Leung, K. C. (2015). Preliminary empirical model of crucial determinants of best practice for peer tutoring on academic achievement. Journal of Educational Psychology, 107(2), 558-579. https://doi.org/10.1037/a0037698

[11] Ungvarsky, Janine (2017), Mastery learning, Salem Press Encyclopedia

[12] Susilowati, dkk. (2009). Pembelajaran kelas rangkap. Direktorat Jenderal Pendidikan Tinggi Departemen Pendidikan Nasional

[13] Suwarno wiji (2006). Dasar-Dasar Ilmu Pendidikan, Jogjakarta, ArRuzz, , Cet. I, April

[14] Joyce Bruce, Marsha Weil,Emily Calhoun (2011), Models Of

Teaching, Terj. Model-model Pembelajaran, Yogyakarta:Pustaka Pelajar

[15] Hill, F. Winfred (2010), Theories Of Learning Teor-Teori Pembelajaran, Konsepsi, Komparasi dan Signfikansi, Terj. M. Khozim, Nusa Media, Bandung, Cet. III, Januari

[16] Guskey, T. R. (2010). Lessons of Mastery Learning. Educational Leadership, 68(2), 52-57. Retrieved from 
http://rlib.pace.edu/login?url=http://search.ebscohost.com/login.aspx

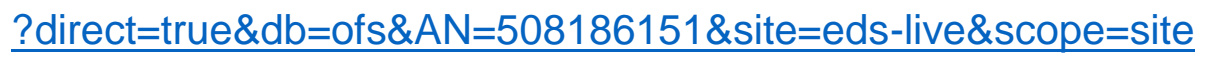

[17] Udkowsky, R., Park, YS, Lineberry, M., Knox, A., \& Ritter, EM (2015). Menetapkan standar penguasaan pembelajaran. Kedokteran Akademik, 90 (11), 14951500. https://doi.org/10.1097/ACM.0000000000000887 